Discourse and Communication for Sustainable Education, vol. 10, no. 2, pp. 49-59, 2019

\title{
Self-Efficacy in Social Science
}

\author{
Gerlinde Pröbstl and Kerstin Schmidt-Hönig \\ University Teacher College, Vienna/Krems, Austria
}

\begin{abstract}
In order to manage the challenges of the $21^{\text {st }}$ century, the assessment of individual selfefficacy constitutes an important factor in the educational context; both on the personal as well as on the social and organisational level. This fact justifies the consideration of self-efficacy as a basic competence, whose development must be started on the primary level. Pupils and teachers realise the resources that contribute to the development of a successful self-concept: increased motivation, a courageous selection of tasks to be fulfilled, and the possible influence on future social and economic developments. During their formation pedagogues are learners and teachers at the same time. In their lectures they deal with Social Entrepreneurship Education and competences connected with it. They reflect their own potential to exert influence and develop strategies to support pupils/students in the development of their own self-concept. In accordance with current findings the re-formulation of the curriculum of primary and secondary level demonstrates a development towards conceptual learning in larger contexts, following the principles of self-guidance and activity-orientation.
\end{abstract}

Key words: self-efficacy, self-concept, social entrepreneurship education (SEE), action competence.

\section{Introduction}

In order to participate successfully in the sustainable development of our society and economy it is necessary to develop fundamental sustainability competences. The educational sector makes it possible for pedagogues to promote the strengths of their pupils in a supportive and guiding manner and to sensitise them with regard to selfefficacy. In this article we will deal with the following questions:

1. What is the importance of self-efficacy in the context of Social Entrepreneurship Education (SEE)?

2. How can self-efficacy in social sciences be made visible taking SEE as an example?

3. What contribution can the formation of primary level pedagogues make? 


\section{The Concept of Self-Efficacy as Basis of the Development of Social Entrepreneurship Competences}

The term self-efficacy, found in English research literature, has been translated in various ways in relevant German literature. In particular, practitioners in the field of psychology and school have made use of it with different focuses. What seems most relevant in the context of Social Entrepreneurship Education (SEE) are the research findings concerning the Social Cognitive Theory of Albert Bandura from 1977 (Bandura, 1995 ) and later investigations, e.g. those by Carina Fuchs (2005).

Entrepreneurship Education in its wider sense comprises all the educational measures which are required to accumulate specialized knowledge, to develop certain values and attitudes for an independent, responsible lifestyle as well as capabilities and skills which are necessary for a successful participation in the economic processes (BMBWF, 2019). The educational focus lies with individuals who, by their way of thinking, their activities and social decisions, become efficient themselves in the social and economic context. This justifies a brief outline of the theory of self-efficacy.

In his Social Cognitive Theory, Albert Bandura focuses on the inner process of personal assessment of one's own capabilities concerning the completion of the tasks in hand. The resulting methods applied in practice yielded success in the treatment of fears, depressions and addictions. With the help of insights in self-efficacy, successes on the individual and group level could be verified in professional and sporting activities. "Perceived self-efficacy refers to beliefs in one's capabilities to organize and execute the courses of action required to manage prospective situations" (Bandura, 1995, p. 2). On account of investigations at different levels (individual, social, organizational levels), Albert Bandura's concept seems to be especially apt for the educational sector, since it comprises these three levels. In the school context this means that pupils and teachers become efficient as individuals but also collectively as part of the school community. It has to be noted, however, that comprehensive empirical investigations concerning the formation and influence of collective self-efficacy of teachers remains to be carried out. Equally, there is only a small sample of statements concerning the self-efficacy of head teachers / directors. According to Bandura's research (1995 and 1977), there are five relevant sources to assess individual self-efficacy:

- mastery experience,

- vicarious experience,

- social persuasion,

- physiological and emotional states,

- integration of efficacy information.

Subsequently, the information obtained in this way undergoes an individual, cognitive procedure of assessment and processing. What follows is the assessment of one's own capabilities and resources to tackle a certain challenge and, following your own decision, instigate a certain effect. We distinguish between persons with high and low self-efficacy. 


\begin{tabular}{|c|c|}
\hline \multicolumn{2}{|c|}{ Self-efficacy } \\
the conviction that one can master certain situations, \\
can effect something and control one's life
\end{tabular}

Figure 1. Manifestation of self-efficacy (according to Hobmair, 2012, p. 180)

The individual degree of self-efficacy has an effect on the exploitation of the individual's resources, the motivation and the willingness to act. With high self-efficacy it is positive, with a low one negative. Positive or negative assessments of one's self-efficacy have an effect on future tasks as well. Thus, individuals with high self-efficacy demonstrate a higher willingness to accept challenging situations and to handle them with higher commitment and great responsibility (Fuchs, 2005, p. 45); with reference to Locke \& Latham, 1990). Self-efficient actors continually adapt their aims in accordance with their positive comparison between performance and task and enhance their personal satisfaction, which again results in an improved assessment of self-efficacy. According to a study by Schwarzer \& Jerusalem (2002), highly self-efficient individuals came out as highly stressresistant in onerous tasks. "They maintained a mental state of challenge and interpreted their failures as caused by external factors" (Schwarzer \& Jerusalem, 2002, p. 38).

Albert Bandura describes self-efficacy by means of three dimensions: magnitude, strength and generality (Bandura, 1977). In this way the varying degrees of self-efficacy in managing given tasks can be recorded as exactly as possible and can be compared to earlier data of the same individual or other test subjects. Fuchs (2005) deals with the concept of self-efficacy in its everyday usage and describes it as the capability of a person to "be active out of one's own drive and thus effect something". This underlines the individual's capability and willingness to act in a specific situation. In times of social change, economic challenges and important ecologic alterations, the individual's ability to act seems to be especially meaningful. As investigated by Bandura (1977) there is a close relation between the difficulty of a challenge and the strength of self-efficacy. "The magnitude of self-efficacy influences the state of mind, the motivation and performance of an individual and determines to a high degree, which behavior is chosen by individuals and how they react to their environment" (Breker, 2015).

Investigations into the connection between magnitude of self-efficacy and state of mind, especially fear and stress, have made clear that growing general self-efficacy can reduce situational fear and stress. Consequently, individuals who dispose of high awareness of their self-efficacy act more courageously and try to modify the situation towards the positive.

Their high self-efficacy supports these individuals in their solution process, which results in better cognitive performance and higher personal satisfaction.

Schools are excellent places where pupils and teachers are continuously confronted with situations of different content and levels of difficulty. This makes it possible for learners again and again to re-evaluate and further develop their self-concept and trust into their own efficacy. 


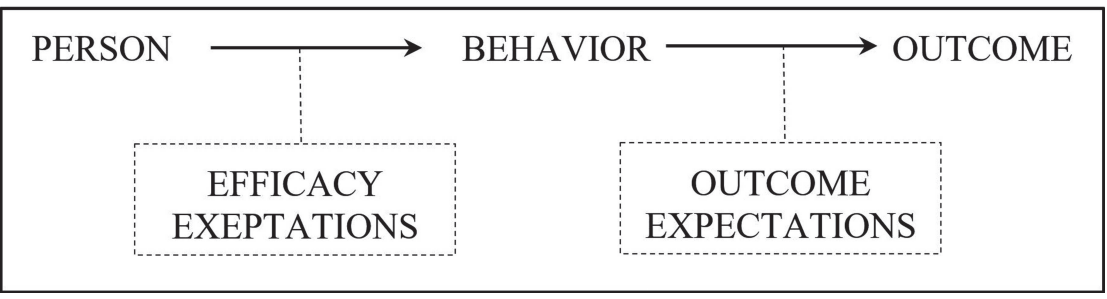

Figure 2. Distinction between efficacy expectation and outcome expectation (according to Bandura, 1977, p. 193)

The traditional concept of a learning process is based on a simple input-output control model with external checks. The current model, however, characterizes it by systemic-constructivist self-organization and accompanying situational intervention. This explains the intensified focus on the inner process of personal assessment of one's abilities concerning a given task and its possible fulfillment. Studies by Köller (2004) with reference to Schwarzer (1992), Ajzen and Madden (1986) distinguish clearly between selfefficient behavior and outcome expectations.

Thus, self-efficacy is solely connected with the assessment of how probable the successful completion of a certain task is. Köller (2004) interprets Bandura's efficacy expectations as a "combination of causality and efficacy convictions". The confidence that children display is closely connected with their self-concept that was developed in various places during their childhood. It is obvious that - apart from school - the parental home and / or the family are among the most important places where one's self-concept is developed. During its development the child's self-concepts starts out with a general notion and is differentiated later in thematic sub-areas, e.g. a performance-oriented, a social, and a physical self-concept (Drechsel \& Prenzel, 2009).

At the age of six to ten years, this differentiation reaches a stage where children can realize strengths and weaknesses; however, the assessment depends notably on the situational context. After the eleventh year, the assessment of one's own self-efficacy gains importance; the reason for that lies in personal experiences and purposeful motivation. In the course of this and the following development stages, continuous negative experiences can reduce the awareness of one's individual self-efficacy (Prenzel, 2000). Positive confirmation, on the other hand, increases the motivation and the readiness to accept challenges.

The ability to create ideas, to plan their implementation, the willingness to realise these plans alone or in company is among the key competences that were elaborated by the European Commission in 2005. This so-called entrepreneurship-competence shows the aim to raise consensus among all stakeholders and to establish a bridge between the worlds of education and work. (Bacigalupo et al., 2016) This key competence also comprises the awareness of ethical values and the promotion of responsible corporate governance.

\section{The Importance of Self-Efficacy in the Area of Social Sciences at Primary Level}

The $21^{\text {st }}$ century confronts humankind with numerous challenges: social ones (climate change, financial security), economic ones (innovation, globalization), technical ones (technologization, digitalization) and personal ones (workplace, happiness, and satisfac- 
tion). Therefore, education for the $21^{\text {st }}$ century comprises four important dimensions: knowledge, skills, character, and metacognition. These must be taken into account in the formation of future generations; what's more, not separately but closely interlinked.

"The Center for Curriculum Redesign addresses the fundamental question of 'What should students learn for the $21^{\text {st }}$ century?' and openly propagates its recommendations and frameworks on a worldwide basis" (Fadel, 2015).

With its frameworks (Fig. 3) the Center for Curriculum Design aims at preparing a basis for future curricula. This endeavor is in agreement with current curriculum development for the teaching of Social Science ("Sachunterricht") in Austria and Switzerland. In Germany the framework for Social Science, elaborated by the Society for Didactics of Social Science (GDSU, 2013) forms the basis for the current curriculum development of the several regions in Germany. What takes place in Austria these days is a redesign of curricula of all subjects on the levels primary and secondary I, aiming at an uninterrupted competence orientation and connectivity.

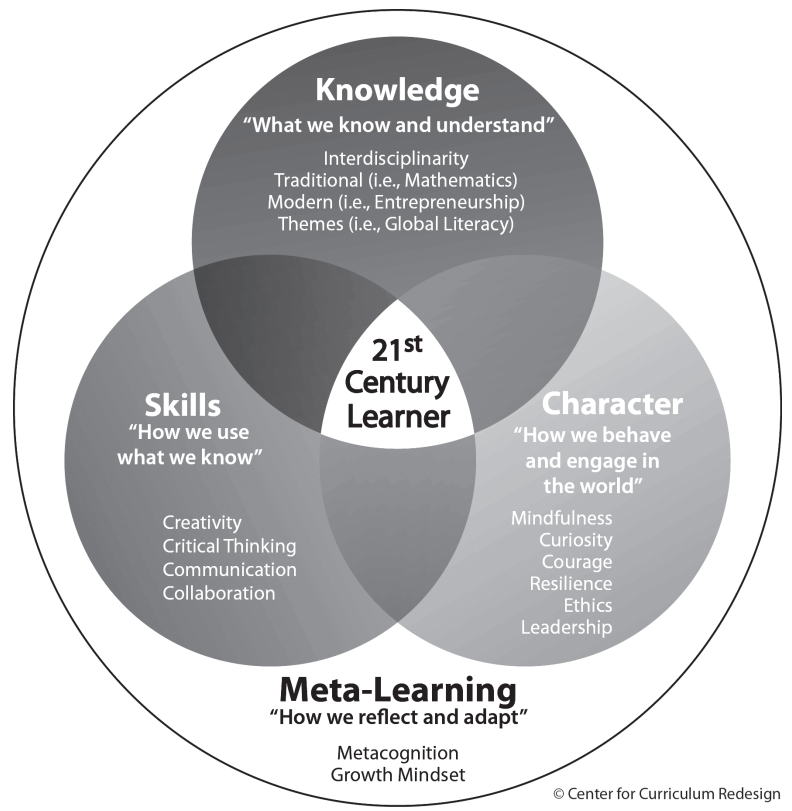

Figure 3. The CCR - Framework for $21^{\text {st }}$ Century Education (Center for Curriculum Redesign, 2017)

The Austrian curriculum for Social Science contains social, historical, political, geographical, and ecological fields of study, which are being treated under many perspectives taking into account possible links to other subjects. The current redesign of the Social Science curriculum considers four fields of competences, which are in accordance with the dimensions of education for the $21^{\text {st }}$ century. Not only is the acquisition of knowledge in the center, but also the development of the child's personality.

- Subject competence (Fachkompetenz) comprises basic notions, contexts, insights of subject-related areas of application and topics, guided by central professional concepts, aiming at assessing acquired knowledge for transfer to new issues and problem areas. 
- Personal competence (Personale Kompetenz) comprises on the one hand the self-competence to realize one's strengths and weaknesses, to learn to assess one's performance, to experience interest, to build self-confidence, to accept responsibility for oneself and the environment. On the other hand, it comprises social competences which concern the co-existence and co-working in the learners' group and social environment; e.g. cooperation, communication, entrepreneurship.

- Deductive competence (Erschließungskompetenz) comprises subject-specific methods and ways of working as well as self-reflective analysis of forms and processes of learning.

- Action competence (Handlungskompetenz) links all areas of competences. Pupils accept responsibilities actively and realize that every action is preceded by some sort of assessment or judgment. By making and justifying judgements, varying perspectives are taken into account; different arguments are being tested, accepted, or discarded. As a consequence, pupils continue developing their system of values and their capability to take over perspectives and empathy (Nowy-Rummel, Radler, \& Schmidt-Hönig, 2019).

According to Conrad and Kalcsics (2018, p. 37), the pupils are to take decisions themselves, act independently in the social context, and reflect their acting. They are to actively participate in the design of their living environment and be able to accept responsibilities for themselves and their community. Giesinger (2017) claims the existence of an up-to-date autonomy, which is necessary to make children into social actors. Pedagogues can foster pupils' experiences of autonomy by

- "intensively dedicating themselves to the (individual) learners and encouraging them,

- providing differentiated learning opportunities and offering space for selfregulated problem-solving,

- structuring contents and communication processes and stimulate the persecution of one's own ideas,

- offering support and demonstrate empathy and takeover of perspectives,

- encouraging the acceptance of one's own responsibility for progress in learning granting opportunities and sufficient time for independent considerations and work,

- behaving in a less monitoring way, refrain from offering solutions and appreciate performance appropriately" (Köhnlein, 2012, p. 271).

At primary level, Social Science is considered a carrier subject in the education for sustainable development (Stoltenberg, 2013). With its singular structure and didactics it offers a broad basis for action-oriented, character-forming learning by means of projects. This includes learning spaces, activities, and events off the premises. Thus self-efficacy is fostered by a high degree of student activity, competence-orientated learning environments, and individualization; but in the first place by an atmosphere of learning free of stress and fear, that is characterized by appreciation, a positive relationship between pupil and teacher and a constructive culture of feedback (Breker, 2015).

According to Köhnlein it is "the experience of inclusion and encouraging feedback" that is of vital importance for the development of one's self-concept. He links these with successful learning in accordance with Bandura and demands as prerequisite learning, environments that are "constructive-genetic" (Köhnlein, 2012, p. 89). 


\section{Self-Efficacy in the Formation of Primary Level Pedagogues}

The Austrian Strategy concerning Sustainable Development Education (BMUKK 2008) aims at a change of awareness towards sustainability on the part of learners and teaching personnel. These are the elements the Strategy wants to make use of:

- anchoring in the educational system,

- partnerships and networks,

- development of teachers' competences,

- research and innovation,

- development of scenarios,

- monitoring and evaluation.

The reason, why the development of teachers' competences is especially important, is that already at primary level pedagogues exert considerable influence on the pupils' development of their personality and the experience of self-efficacy. It is imperative to transmit a basic understanding for global connections, to make pupils aware of future challenges and to educate them to be global world citizens (Schmidt-Hönig, 2019, p. 141).

What is especially meaningful in the context of Social Science is the linkage of knowledge concerning subject, subject-specific didactics, and pedagogical psychology (Zadeh \& Peschel, 2018, p. 184). Pedagogues should be aware of the individual pupil's probable abilities and characteristics and take these into consideration while planning and designing the learning process (Kahlert, 2009, p. 76). This includes not only the pupils' previous knowledge, but also their personalities and at first their self-concepts.

A teacher's positive self-concept is considered an indicator of his or her professional action competence, which in turn influences the self-concept of the individual pupil. "In general we define self-concept both as perception as well as mental representation of one's own individual abilities and talents" (Möller \& Trautwein, 2015). In this way the awareness of one's individually shaped self-efficacy is one of the essential entrepreneurship competences.

Among these competences Mertens (1974) distinguishes between "basic qualifications" and "horizontal qualifications." Self-efficacy manifests itself as basic competence by critical, structuring, dispositive thinking as well as co-operative and creative approaches in the problem-solving process (Lindner, 2015).

Therefore one of the aims in the training of primary and secondary pedagogues should be the development of an awareness of the meaningfulness of self-efficacy in society and economy. The recognition of entrepreneurship as key competence results in a clear emphasis on the interdisciplinary and holistic dimension during teacher-formation in order to respond to this demand.

Gibb and Nelson (1996) distinguish three intentions of entrepreneurship education: education "for, through and about entrepreneurship." Entrepreneurial Challenge based Learning offers a possible approach. Actors enjoy a large degree of creative autonomy, responsibility for the implementation and reflection on the results.

At the University Teacher College Vienna/Krems it is possible for future pedagogues to get to know this practice-oriented concept headed by Gerlinde Pröbstl. During their lectures students acquire cognitive knowledge; at the same time they broaden their experience in their Practical Pedagogical Studies - for example: following the TRIOModell (Lindner, 2018) pupils develop their own projects directed and accompanied by soon-to-be teachers. Uniting these two interacting strands the concept is further advanced 
and accompanied by intensive phases of reflection during the Practical Pedagogical Studies. What is important here is the cooperation between students and teachers in the department "Sachunterricht" and "socio-cultural focus", as well as students and mentors at the practical training schools. Students receive practical input during their lectures, practical hints for their classes by attended lesson-planning and the presentation of upto-date materials and methods; for example: in the course of the seminar "Global relations between man and environment and challenges concerning the usage of resources" (KPH Wien/Krems). The objective is to prompt students to reflect and consciously design the manifold roles in living environments shaped by economy, society and politics (Pichler, Fridrich, Vielhaber, \& Bergmeister, 2017).

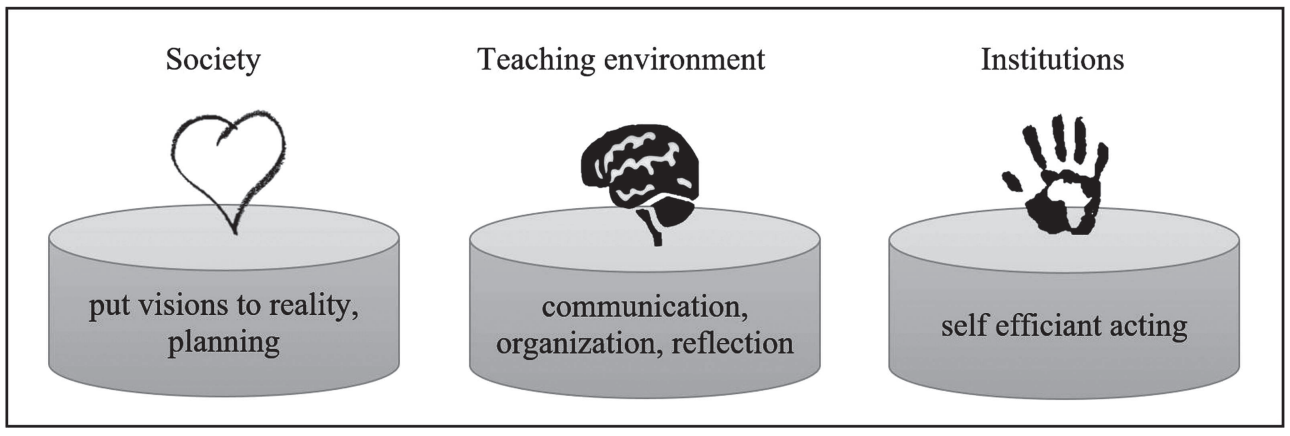

Figure 4. Developing self-efficacy (Pröbstl, 2018)

The concept is based on competence areas, with specific target groups (pupils, students, and teachers), the basic elements, however, remain the same. This specification concerns the complexity of factual knowledge, the choice of materials and methods or the social format. In the center of this concept are the competences in the area of SEE that teachers or soon-to-be teachers already master or want to develop (factual and methodological knowledge, for instance domain-specific knowledge concerning SEE). In the conflicting areas of society on the whole and institution (school / university / training institutes), we create a teaching environment that makes it possible to develop on different levels the aspects (a) "planning and developing visions", (b) “communicating, reflecting, and organizing”, and (c) “acting” (i.e. becoming effective oneself, realize projects).

Self-effective actors generate ideas and above all use these implementations of new ideas in developing society and economy.

In the future we plan to carry out investigations into the teaching practice of primary level pedagogues who, in the course of their formation, have been made familiar with the aspects of self-efficacy in the area of SEE. The central question is: To what extent or in what areas could the confrontation with the aims of SEE create a lasting influence on the lessons of the pedagogues?

Further sub-questions deal with the competence that are contained in the given model, e.g. is the current scientific status incorporated in the factual area of the topic? Does the trainee also value these aspects of personal development or the evolution of values and not only separate complex knowledge? 


\section{Conclusion}

The ability to create ideas, to plan their implementation, the willingness to realise these plans alone or in company is among the key competences which are based on high self-efficacy.

Students in their pedagogical formation are to a high extent teaching and learning subjects at the same time. That means that they themselves - in the course of their practical teaching - acquire competences and transmit knowledge to their pupils. That fact is highly appropriate for the perception of complex connections like those who characterize many social and economic processes.

Future investigations will show how far our school system in its present organizational status is apt to develop individual self-efficacy, or if it will be organized in a different way along the new curriculum.

What we need in order to respond to the challenges of the $21^{\text {st }}$ century are competent individuals, capable of assessing their own efficacy and to develop their own ability to act. Motivated pedagogues, equipped with a positive self-concept, need to accompany this development.

\section{References}

Bacigalupo, M., Kampylis, P., Punie, Y., \& Van den Brande, L. (2016). EntreComp: The entrepreneurship competence framework. Brussels: Publications Office of the European Union.

Bandura, A. (1995). Exercise of personal and collective efficacy in changing societies. In Bandura, A. (Ed.), Self-efficacy in changing societies (pp. 1-45). Cambridge: Cambridge University Press.

Breker, T. (2015). Fähigkeitsselbstkonzept, Selbstwirksamkeit \& Mindset - Wie können Lehrkräfte Erkenntnisse aus der Sozial-Kognitiven-Psychologie nutzen, um die Potenzialentfaltung von Schülerinnen und Schülern zu fördern? [Ability self concept, selfefficacy \& Mindset - How can teachers use insights from social-cognitive psychology to promote the development of students' potential?]. Dissertation. Frankfurt/Oder: Europa-Universität Viadrina.

BMUKK - Bundesministerium für Unterricht, Kunst, Kultur. (Eds.). (2008). Österreichische Strategie für nachhaltige Entwicklung [Austrian strategy for sustainable development]. Wien: BMUKK.

BMBWF - Bundesministerium für Bildung, Wissenschaft und Forschung. (2019). Entrepreneurship education. Retrieved from https://bildung.bmbwf.gv.at/schulen/bw/bbs/ entrepreneurship.html

BKA - Bundeskanzleramt. (2013). Nachhaltige Entwicklung - Agenda 2013/ SDGs [Sustainable development - Agenda 2013/SDG]. Retrieved from www.bundeskanzleramt.gv.at/nachhaltige-entwicklung-agenda-2030

Centre for Curriculum Redesign. (2017). Framework for $21^{\text {st }}$ century education. Retrieved from https:/curriculumredesign.org/wp-content/uploads/CCRVennDiagram Print.png. (27.8.2019)

Chen, J. A., \& Usher, E. L. (2013). Profiles of the sources of science self-efficacy. Learning and Individual Differences, 24, 11-21. Retrieved from www.sciencedirect.com/ science/article/pii/S1041608012001707 
Conrad, S. J., \& Kalcsics, K. (2018). In der Welt handeln "und das Paradox von Bilden und Partizipieren in der Schule ["Acting in the world" and the paradox of education and participation in schools]. In Franz, U., Giest, H., Hartinger, A., HeinrichDönges, A., \& Reinhoffer, B. (Eds.), Handeln im Sachunterricht [Acting in social science] (pp. 37-44). Bad Heilbrunn: Klinkhardt.

Drechsel, B., \& Prenzel, M. (2009). Motiviert lernen [Motivated learning]. Grundschule [Journal for Primary School] 10/2009. Braunschweig: Westermann, 18-20.

Fadel, C. (2015). Redesigning the curriculum for a $21^{\text {st }}$ century education. Retrieved from http://curriculumredesign.org/wp-content/uploads/CCR-FoundationalPaper_ FINAL.pdf. (27.8.2019)

Fadel, C., Bialik, M., \& Trilling, B. (2017). Die vier Dimensionen der Bildung. Was Schülerinnen und Schüler im 21. Jahrhundert lernen müssen [The four dimensions of education. What pupils need to learn in the $21^{\text {st }}$ century]. Hamburg: Verlag ZLL21e.V.

Fuchs, C. (2005). Selbstwirksam Lernen im schulischen Kontext [Self-effective learning in a school context]. Bad Heilbrunn: Klinkhardt.

Giesinger, J. (2017). Kinder und Erwachsene [Children and adults]. In Drerup, J., \& Schickhardt, C. (Eds.), Kinderethik. Aktuelle Perspektiven - Klassische Problemvorgaben [Ethics of children. Contemporary perspectives - classical specifications] (pp. 21-32). München: Mentis.

Hobmair, H. (2012). Pädagogik [Pedagogy]. Köln: Bildungsverlag EINS.

Kahlert, J. (2009). Der Sachunterricht und seine Didaktik [Social science and its didactics]. Bad Heilbrunn: Klinkhardt.

Köhnlein, W. (2012). Sachunterricht und Bildung [Social science and education]. Bad Heilbrunn: Klinkhardt.

Köller, O. (2004). Konsequenzen von Leistungsgruppierungen [Consequences of performance groupings]. Münster: Waxmann.

Lindner, J. (2015). Entrepreneurship Education für Jugendliche [Youth entrepreneurship education]. Retrieved from www.gw-unterricht.at

Lindner, J. (2018). Entrepreneurship education for a sustainable future. Discourse and Communication for Sustainable Education, 9(1), 115-127.

Lindner, J., \& Hueber, S. (2017). Entrepreneurship Education für Volksschüler/innen [Entrepreneurship education for kids at primary school]. Erziehung und Unterricht, März/April [Journal for Education and Instruction, March/April] 3-4/2017. Wien: ÖBV.

Möller, J., \& Trautwein, U. (2015). Selbstkonzept [Self-concept]. In Wild, E., \& J. Möller (Eds.), Pädagogische Psychologie [Pedagogical psychology] (pp. 178-199). Springer: Heidelberg.

Nowy-Rummel, S., Radler, M., \& Schmidt-Hönig, K. (2019). Lehrplanentwurf [Curriculum draft]. Internal Working Paper.

Pichler, H., Fridrich, C., Vielhaber, C., \& Bergmeister, F. (2017). Der Fachdidaktische Grundkonsens 2.0 in der Verbundregion Nordost [The basic didactic consensus 2.0 in the region Northeast]. GW-Unterricht [Journal for Geography and Economic Instruction], 146, 60-62.

Prenzel, M. (2000). Interessenentwicklung in Kindergarten und Grundschule-Die ersten Jahre [Development of interests in kindergarten and primary school - the first years]. In Schiefele, U., \& Wild, K. P. (Eds.), Interesse und Lernmotivation. Untersuchungen 
zu Entwicklung, Förderung und Wirkung [Interest and learning motivation. Studies on development, support and impact] (pp. 11-30). Monster: Waxmann.

Pröbstl, G. (2018). Projektbericht [Project report]. Internal: KPH Wien/Krems.

Rauch, F., Streissler, A., \& Steiner, R. (2008). Kompetenzen für Bildung für Nachhaltige Entwicklung. Konzepte und Anregungen für die Praxis [Competences for education for sustainable development. Concepts and suggestions for practice]. Wien: BMUKK.

Schmidt-Hönig, K. (2019). Sozial- und kulturwissenschaftlicher Sachunterricht im Anfangsunterricht [Social and cultural science lessons in the beginning]. In Fajtak, U., \& Schmidt-Hönig, K. (Eds.), Schuleingangsphase erleben und gestalten [School entrance phase - experience and designing] (pp. 133-152). Wien: LIT Verlag.

Schwarzer, R., \& Jerusalem, M. (2002). Das Konzept der Selbstwirksamkeit [The concept of self-efficacy]. In Jerusalem, M. \& Hopf, D. (Eds.), Selbstwirksamkeit und Motivationsprozesse in Bildungsinstitutionen. Zeitschrift für Pädagogik, Beiheft [Selfefficacy and motivation processes in educational institutions. Journal for pedagogy, supplement] (pp. 28-53.44). Weinheim: Beltz.

Stoltenberg, U. (2013). Sachunterricht für das 21. Jahrhundert - Weltorientierung durch Bildung für eine nachhaltige Entwicklung [Social science education for the $21^{\text {st }}$ century - world orientation through education for sustainable development]. In Weltorientierung durch Bildung für eine nachhaltige Entwicklung. Theoretische Grundlagen und Praxis des Sachunterrichts in der Grundschule [World orientation through education for sustainable development. Theoretical basics and practice for social and science studies in primary school] (pp. 13-15). Bad Homburg: VAS.

United Nations. (2015). Sustainable development goals. Retrieved from https://sustainable development.un.org

Zadeh, M., \& Peschel, M. (2018). Self Pro - Entwicklung von Selbstkonzepten beim Offenen Expermentieren [Development of self-concepts in open experimentation]. In Franz, U., Giest, H., Hartinger, A., Heinrich-Dönges, A., \& Reinhoffer, B. (Eds.), Handeln im Sachunterricht [Acting in social and science studies] (pp. 183-190). Bad Heilbrunn: Klinkhardt.

Correspondence relating this paper should be addressed to Gerlinde Pröbstl, University Teacher College, Vienna/Krems, and University of Vienna, Department of Geography and Regional Research. Email: gerlinde.proebstl@kphvie.ac.at

or to Kerstin Schmidt-Hönig, University Teacher College, Vienna/Krems. Email: kerstin.schmidt-hoenig@kphvie.ac.at 